\title{
Tidal River Management (TRM) and Tidal Basin Management (TBM): A case study on Bangladesh
}

\author{
Rocky Talchabhadel ${ }^{1, a}$, Hajime Nakagawa ${ }^{2}$ and Kenji Kawaike ${ }^{2}$ \\ ${ }^{1}$ Ph. D. Student, Dept. of Civil and Earth Resources Engineering, Kyoto University \\ (Shimomisu, Yoko-oji, Fushimi-ku, Kyoto 612-8235, Japan) \\ ${ }^{2}$ Professor, Dept. of Civil and Earth Resources Engineering, Kyoto University
}

(Shimomisu, Yoko-oji, Fushimi-ku, Kyoto 612-8235, Japan)

\begin{abstract}
Bangladesh is the biggest delta of the world. Construction of numbers of polders is one of the flood resilient approach. But the presence of coastal polders de-linked the flood plain. The siltation in river causes riverbeds to become higher than the adjacent crop lands, and vast area under the polders became permanently water logged rendering large tract of land uncultivable. The current practice is temporarily de-poldering by cutting embankment. This is a natural water management process with very little human interventions but it needs strong participation and consensus with a great deal of sacrifice by the stakeholders for a specific period ( 3 to 5 years or even more)[1]. An attempt has been made to study the phenomena of tidal basin management reviewing some secondary data and processes involved in successfully operated tidal basins of Bangladesh. And preliminary laboratory experiments are carried out to precisely look into the suspended sediment transport. With varying outflow discharge and sediment supply, the transport processes are investigated. 3D sediment transport model developed using openFOAM has good agreement with experimental result and can be used to better understand effectiveness of tidal basin management.
\end{abstract}

\section{Introduction}

With about half of its surface below the $10 \mathrm{~m}$ contour line, Bangladesh is located at the lowermost reaches of three mighty river systems - Ganges , Brahmaputra and Meghna [2](shown in Fig. 1). In earlier decades before 1960 s, when polders were not constructed, lowlying areas of coastal zone were frequently flooded by salt water during high tide [3]. In order to increase agricultural production, a series of polders enclosing the low-lying coastal areas was built [4]. The presence of coastal polders de-linked the flood plain. Due to confinement of the rivers by the polders, rivers gradually started to be silted up, and by 1980s, many of the riverbeds became higher than the adjacent crop lands and vast area under the polders became permanently water logged, rendering large tract of land uncultivable [5].

In the 1990s, government initiated a drainage congestion removal project, which later adopted the tidal basin concept according to the demand of the local people. Temporary de-poldering is done and certain areas are to be kept aside as tidal floodplain so that sediments can be deposited on the floodplain rather than on the rivers itself. Such tidal basins are to be rotated among various lowlands within the system so that farmers of one

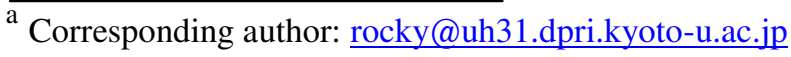

tidal basin do not have to suffer for long time, the process known as Tidal Basin Management (TBM).

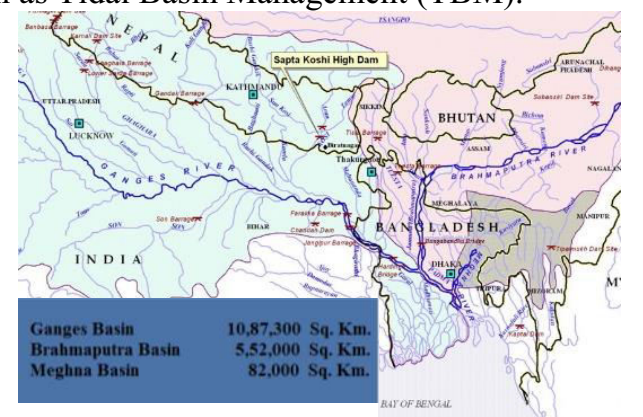

Fig. 1 The catchments of the Ganges, Brahmaputra and Meghna Source: www.jrcb.gov.bd/image/Basin_map.jpg

The estuarine rivers in the southwest coastal region witness two cycles of tides in every day. The high tides bring in muddy water flow with a high concentration of sediments [6]. The cut at the embankment, in an appropriate point, lets the river flow enter a floodplain. The natural high tide of river enters the floodplain, leaves a part of the sediment to be deposited on the floodplain and goes back to the sea $[5,6]$. Over time, the deposition 
of sediments raise land level in the floodplain and enriches the soil. Since this process does not allow sediments to be deposited on riverbed, the depth of the riverbed also increases and makes the river congestion free [6]. Such process of river management is named as Tidal River Management (TRM).

The beel is a Bengali term used for relatively large surface, static waterbody that accumulates surface run-off water through an internal drainage channel [7]. This type of shallow, seasonal waterbody is common in low-lying floodplain areas throughout Bangladesh [8]. The major purpose of TBM/TRM is to get suspended sediment deposits gradually under a controlled system on selected tidal beel [9]. TRM is an environment friendly, cost effective and economically viable process to raise coastal lands for enhancing agricultural opportunities [10].

An attempt has been made to study the phenomena of TBM reviewing secondary data and processes involved in successfully operated tidal basins of Bangladesh: the public cut in beel Bhaina (1997-2001) and two official cuts of beel Kedaria (2002-2005) and east beel Khuksia (2006-2012). Furthermore preliminary laboratory experiments and numerical simulations are carried out to precisely look into the suspended sediment transport.

\section{Data and Methods}

Data were collected from secondary literature. Secondary data sources both published and unpublished records such as books, thesis papers, newspapers, articles, magazines, reports of NGOs, different government and non-government project works etc were used to enrich to study. Key issues addressed included processes involved in three operated tidal basin management, sedimentation processes at beel and morphological changes in river. Additionally preliminary experiment was conducted using experimental facility. Experimental collected data were used to understand the complex process of sediment dynamics and were compared with preliminary numerical simulation.

\subsection{Literature Review}

Before the Coastal Embankment Project, the floodplains were used only part of the year to grow crops; the remainder of the year they were used for fishing purposes. They used to construct small embankment during 6-8 months of the year, in order to protect rice against saline intrusion in dry season.

In context of Bangladesh, observing decadal timescale, the processes could be roughly categorized as follow:

-Coastal Embankment Project in the 1960s

- Good crop production in the 1970 s

-Drainage congestion in the $1980 \mathrm{~s}$

-Drainage rehabilitation project in the 1990s

- Tidal basin operation in 2000s

-Tidal basin not operational in 2010s
3 operated tidal basins shown in Fig 2 were investigated specifically to understand processes of tidal basin management. Other beels apart from these 3 basins were also studied.

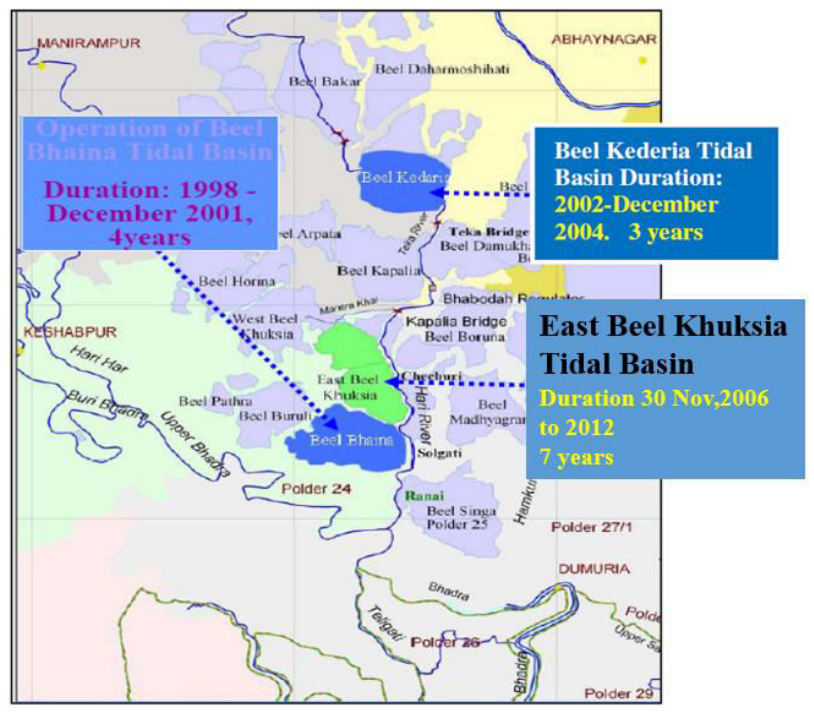

Fig 2. Successfully operated three tidal basins [11]

\subsection{Experimental Setup}

The experiments were carried out in a flume located at the Ujigawa Open Laboratory (UOL) of Disaster Prevention Research Institute (DPRI), Kyoto University. The schematic view of the experimental setup is shown in Fig. 3. Several parameters were measured during the experimental studies, namely: 2D water surface velocity by PIV techniques, velocity by electromagnetic current meter, bed profile by laser displacement sensor, surface water level by ultrasonic sensor and water discharge by bucket method.

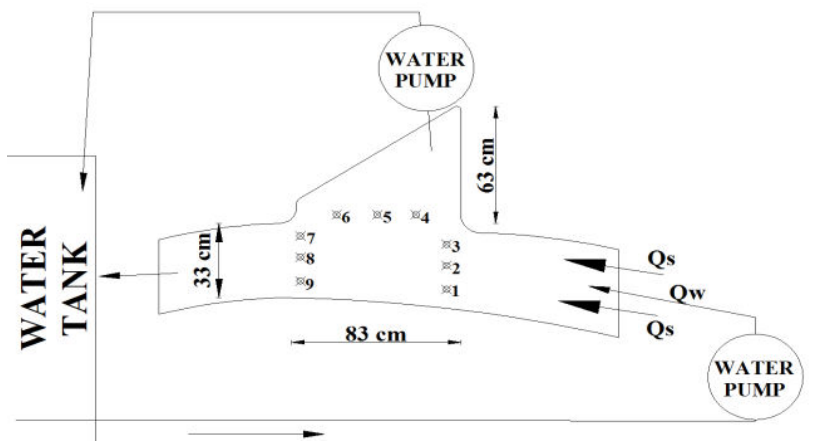

Fig.3 Schematic view of the experimental setup [12]

3 portions were attempted to study precisely. They are inlet, side basin and outlet. 9 sampling points namely $1-9$ representing inlet by $1-2-3$, side basin/tidal beel by 4-5-6 and outlet by 7-8-9 as shown in Fig. 3 were adopted to study sediment behaviour. All experiments were conducted using a constant flow discharge of $125 \mathrm{l} / \mathrm{min}$ (Qw) in experimental flume, referred to as inflow and were limited to fixed bed. Dry sediment of mean diameter equal to $80 \mu \mathrm{m}$ and density $1.76 \mathrm{gm} / \mathrm{cc}$ was fed from adjustable sediment feeder. 


\subsection{Numerical Simulation}

OpenFOAM (Open Field Operation and Manipulation) is primarily a $\mathrm{C}++$ toolbox for the customisation and extension of numerical solvers for continuum mechanics problems, including computational fluid dynamics (CFD). It comes with a growing collection of prewritten solvers applicable to a wide range of problems. It is produced by UK Company OpenCFD Ltd. and is released open source under the GPL $[13,14]$.

The governing equations are the 3D continuity and RANS equations for incompressible flows and the advection equation of the F-function used in the VOF method, which can be written in the vector form as

$$
\begin{gathered}
\nabla \cdot \mathbf{U}=\mathbf{0} \\
\frac{\partial \rho \mathbf{U}}{\partial t}+\nabla \cdot(\rho \mathbf{U U})=-\nabla p+\nabla \cdot \boldsymbol{\tau}+\rho \mathbf{g}+\mathbf{f}_{\mathrm{s}}
\end{gathered}
$$

$$
\frac{\partial F}{\partial t}+\nabla \cdot(\mathbf{U} F)=0
$$

where $\nabla=$ the three-dimensional gradient operator, $\mathrm{U}$ $=$ the flow velocity vector, $\rho=$ the fluid density, $p=$ the pressure, $\tau=$ the viscous stress tensor, $\mathrm{g}=$ the gravitational acceleration vector, and fs = the body force equivalent to the surface tension. The step function $\mathrm{F}$ used in the VOF method is defined to be one at cells occupied by water and zero at cells occupied by air. Cells with F-function between zero and one contain water surface. In order to solve the velocity-pressure coupling, the PISO (pressure implicit with splitting of operator) approach was adopted. The finite volume method (FVM) was used for discretization, the second-order central difference method for spatial discretization and the firstorder implicit method for temporal discretization.

The trajectory of bed load motion is calculated by the Lagrangian method with the motion equation of a bed load particle. Some of bed load particles transit to the suspension due to fluctuating vertical flow velocity, and conversely suspended load returns to bed load due to gravitational settlement. The suspended load transport is solved by the Eulerian method with typical advectiondiffusion equation. The Lagrangian model and the Eulerian model are connected by sediment exchange between bed load motion and suspension. The bed surface deforms due to sediment exchange (i. e. pick-up and deposition) between bed load and stationary bed [15].

\section{Results}

\subsection{Secondary Data Review}

During the drainage rehabilitation project, 9 Water Management Associations (WMA) were established, and 68 Water Management Groups (WMG). The WMAs were established based on hydrological boundaries, and WMGs were established in villages or groups of villages.

Beel Bhaina has benefitted considerably from the sediment deposition. Farming practices are diverse in beel Bhaina: most farmers grow rice from February to April, cultivate salt water Bagda shrimp from May to July and sweet water Golda shrimp from August to December. Sediment deposition in the basin is high at close to the opening and less at the furthest end of the basin, which varies from few 10 of $\mathrm{cm}$ to more than $2 \mathrm{~m}$.

The land levels in beel Bhaina and east beel Khuksia were raised by approximately $80 \mathrm{~cm}$ and $1.5 \mathrm{~m}$ respectively. In case of beel Kedaria, its impact was not so much significant which might be due to its position of cut where tidal influence is very less (approximately $0.20 \mathrm{~m}$ in contrast to approximately $2.00 \mathrm{~m}$ in beel Bhaina). But there was no drainage congestion during the operation of beel Kedaria tidal basin.

Beel Khuksia has been a tidal basin for 7 years, but the initial plan was to only open it for 3 years. Beel Kapalia was planned to be inundated from 2012 onwards for a period of 5 years, but violent protests on June 2nd prevented this. Some of the reasons are compensation mechanism, officially land was not registered with government and lack of trust in government.

Much land in beel Kapalia and possibly also in other beels was abandoned by Hindus in 1948 when (East) Pakistan and India separated. This land was taken by Muslim settlers and never formally registered, which poses problems with the compensation process in beel Kapalia today. Moreover such extreme viewpoint can be partly attributed to the economic interests of the (shrimp) farmers, who do not want to lose their leased land under any circumstances. Some are landless people who will lose their day job of cultivating in that land. Additionally, they seem to have lost trust in government completely.

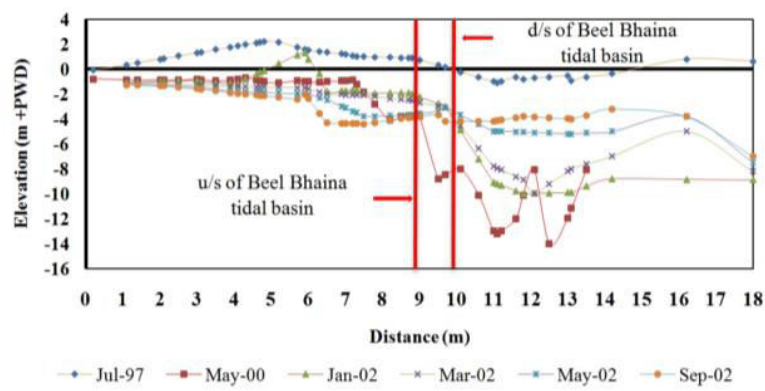

Fig 4. Temporal variation of profile of Hari River [16]

The Hari River, which was heavily silted up before implementation of TRM in beel Bhaina tidal basin, was triple its width within only two years of TRM operation and its depth consequently increased to almost $10 \mathrm{~m}$ just downstream of the basin [16]. Fig 4 shows the temporal variation of long profile of Hari River. 


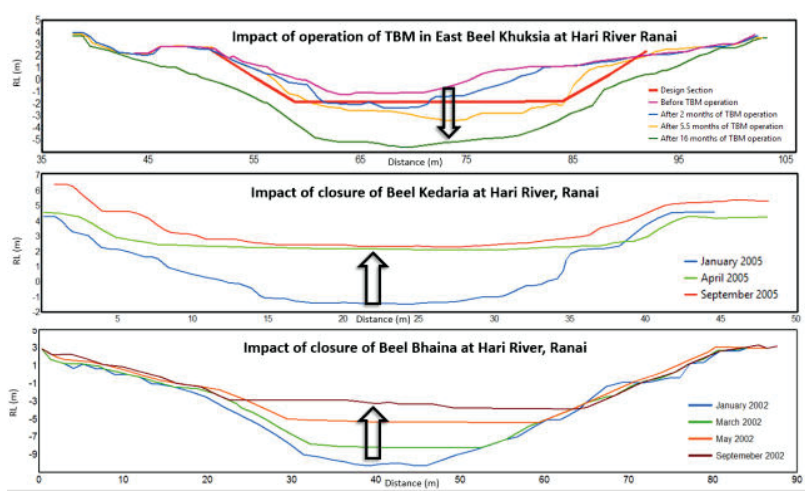

Fig 5. Impact of operation and closure of TRM at Hari River during different time [17]

In July 1997, the river was shallow due to regular siltation whereas in May 2000, river bed in the immediate upstream of Beel Bhaina tidal basin dropped by $4 \mathrm{~m}$ below MSL and at some downstream locations, bed elevation dropped by around $14 \mathrm{~m}$. Due to TRM, sediments carried by the river were deposited inside the basin, causing heavy scouring river bed at downstream of beel Bhaina tidal basin.

During implementation of TRM in beel Kedaria (after beel Bhaina), which is located around $11 \mathrm{~km}$ downstream of beel Bhaina, river reach along beel Bhaina tidal basin continued to be silted up again (Fig 4 and 5). Similarly impact of operation of TRM in east beel Khuksia and closure of beel Kedaria also shows similar process of bed aggradation in river after closure whereas deepening after operation of TRM. As shown in Fig. 5, the operation of TRM in east beel Khuksia resulted deepening of cross section of river even deeper than designed section. The closure of TRM resulted substantial siltation of river bed in few months.

\subsection{Experimental Setup and Numerical Simulation}

\subsubsection{Experimental Results}

With varying outflow discharge from side basin, sediment concentration at inlet (1-2-3) is almost constant. But it has significant effects in outlet (7-8-9) and side basin (4-5-6). Sediment concentration is increasing in side basin (4-5-6) whereas decreasing in outlet (7-8-9) with increase in discharge at side basin (shown in Fig 6). When higher outflow discharge is allowed to flow from side basin higher sediment is transported towards it and lesser sediment on the course of river [12].

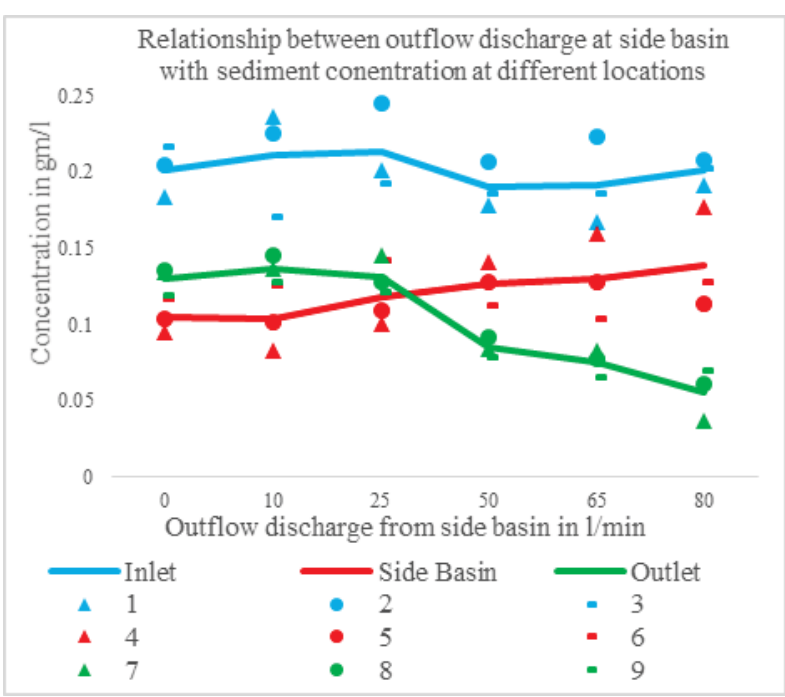

Fig 6. Sediment concentration at 9 sampling points with varying outflow discharge from side basin [12]

It is obvious that increase in concentration at inlet will surely increase concentrations at side basin and outlet. But as shown in Fig 7 distribution of sediment towards side basin to outlet is almost same in all conditions with ratio varying from $1.41-1.67$ particularly in this case with $50 \mathrm{l} / \mathrm{min}$ outflowed from side basin [12]. Lateral widening of side basin here doesn't happen in experimental flume. But in reality when tidal beel is operated, flow channels are laterally also widened resulting more space for large water and sediment discharge to pass.

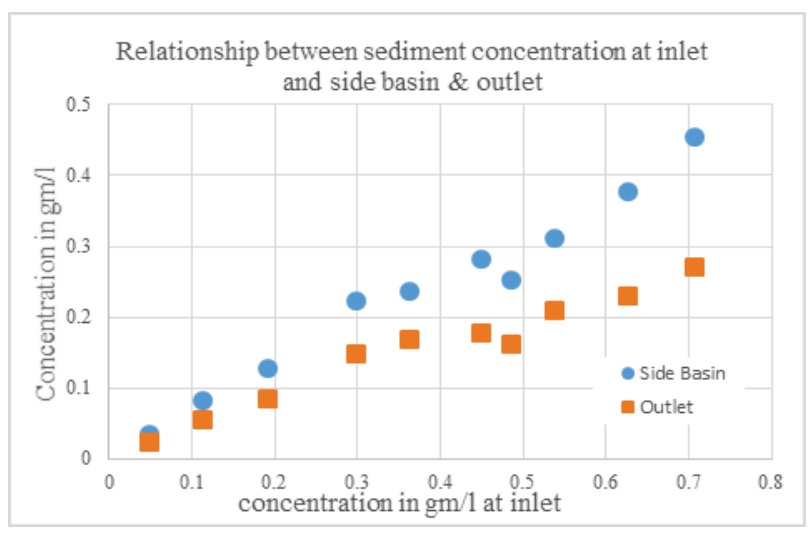

Fig 7. Sediment concentration at side basin and outlet Vs sediment concentration at inlet [12]

\subsubsection{Numerical Simulation}

Fig 8 is the case where outflow from side basin was not allowed to flow and Fig 9 is the case where outflow of $50 \mathrm{1} / \mathrm{min}$ was allowed to flow. To understand the direction of sediment flow, continuous sediment supply was provided during experiment throughout and was also recorded from video camera to analyse through Particle Image Velocimetry (PIV). Fig 8 shows, since water discharge is confined towards outlet, most of sediment is deposited on the way towards outlet whereas Fig 9 shows, since $40-50 \%$ of flow is towards side basin, more sediment is deposited towards side basin. 

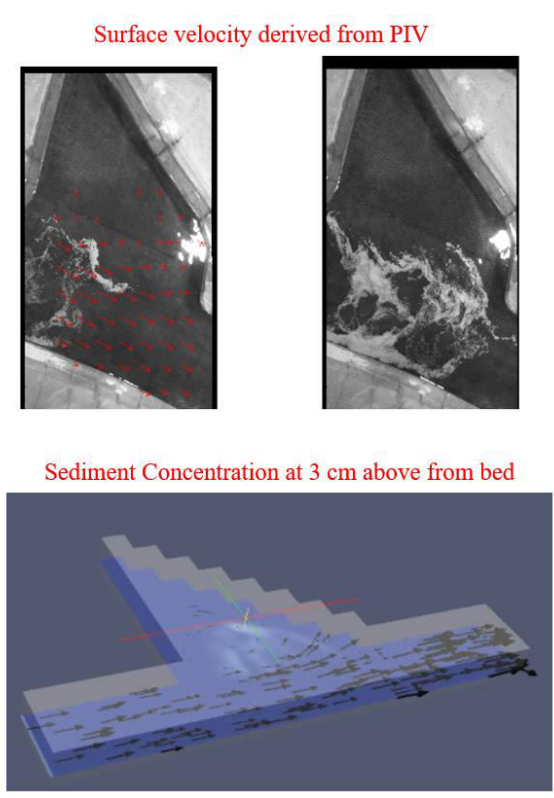

Fig 8. The case where no outflow from side basin

Surface velocity derived from PIV
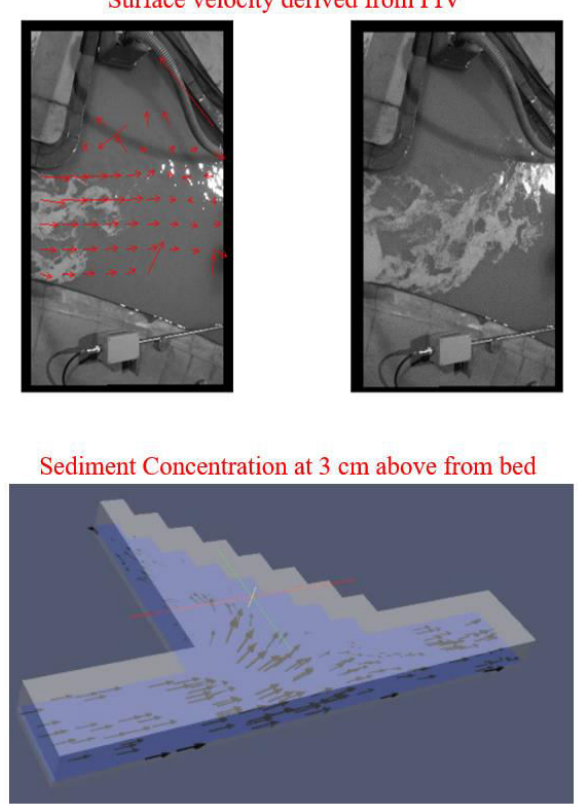

Fig 9. The case where 50 1/min outflowed from side basin

The current experiment has some limitations of shape and size of side basin which here has been attempted to simulate in numerical model. With changing size of opening in straight flume $(30 \mathrm{~cm}, 65 \mathrm{~cm}$ and $100 \mathrm{~cm})$, the transport of suspended sediments are investigated. The next stage experiment for this scenario is currently in progress.

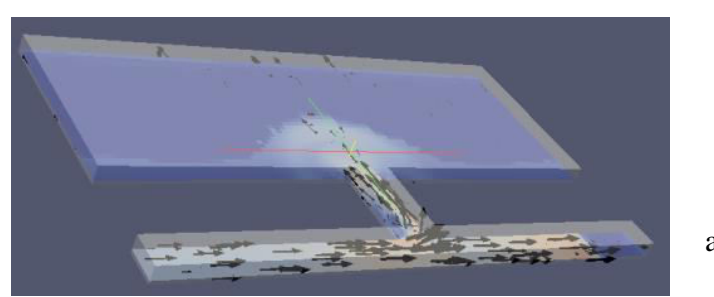

a
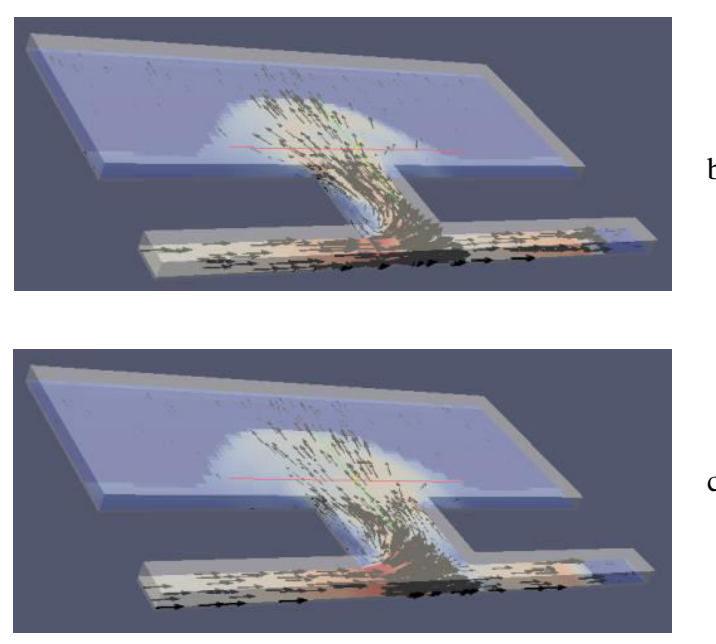

Fig 10. Water velocity at $3 \mathrm{~cm}$ above from bed in different scenario a) $30 \mathrm{~cm}$ opening, b) $65 \mathrm{~cm}$ opening and c) $100 \mathrm{~cm}$ opening

\section{Discussions}

Tidal basins are able to drastically decrease riverbed levels or at least stabilize them. If rotation of TRM beels is not carried out very systematically and in a planned manner, then the incoming tides are more likely to drop their sediment in the river channels themselves, which will further accelerate such deposition.

Tidal basins can be an economically and environmentally friendly way of controlling sediment deposits alternative to dredging and large-scale concrete infrastructure (like regulators). The challenges that pertain are, however, of social and political rather than physical nature.

The burning of 12 government and Bangladesh Water Development Board (BWDB) cars during violent protests against the development of a tidal basin in beel Kapalia in June 2012 can be attributed to the lack of interaction between the BWDB and local informal water management entities. Currently, informal water managers control almost all gates (and thus water levels). The official water management associations and groups established during the drainage rehabilitation project have lost much of their power.

In this context TRM/TBM should be discussed in different dimensions and perceptions like

Does TRM raise the required land level of our Beel?

Is TRM a livelihood threat?

Is TRM method of silt management in river?

Is TRM an indigenous water management practice?

Is TRM enough? Do we need more sediment management practice simultaneously? 
Do we need concrete solutions than TRM?

Since sedimentation determines the life span of basin and the rate of raising the land it is recommended that better understanding of sedimentation process is necessary. One significant hydraulic fact is that the faster the river flow is, the more sediment it can carry with it, as its sediment-carrying capacity is a function of velocity. If direction of flow is made easy towards selected tidal beel, more sediment can be transported and deposited. Those tidal basins where more flow passes have more sediment transport. This might happen due to either large size of tidal basin, large size of openings of beel, proper orientation of intake or larger water holding capacity of beel.

Side basin in current study represents only the entrance of tidal basin. Moreover it has other limitations like fixed bed, no tidal effect, constant inflow discharge, no lateral widening of side basin, shape and size of side basin etc. It has to be expanded in the next experiment with larger size of side basin, availability of facility to address tidal effect and varying size of link canal joining flume and side basin. Next step will be to develop and verify numerical model which would enable to estimate deposition of suspended sediment in side basin taking consideration of tidal effects also.

\section{Conclusions}

Tidal basins can be an economically and environmentally friendly way of controlling sediment deposits alternative to dredging and large-scale concrete infrastructure like regulators in the river. The challenges that pertain are, however, of social and political rather than physical nature. Moreover, effective compensation and adaptation mechanism for those people who are impacted by the inundation needs to be secured. There is a large gap in the interaction between different levels of government and between water management entities on river basin level (BWDB) and the field level (informal water management groups).

From preliminary experiments and simulations, it can be inferred that deposition of suspended sediment mainly depends upon direction of flow and magnitude of discharge limiting no tidal discharge in present context. Field based data of size of tidal beel, topographical condition of beel, sediment concentration at river, tidal effects on discharge, lateral widening process of channel, average deposition of suspended sediment in operated tidal basin are very much important to understand the phenomena of TBM precisely. The current research has to be expanded in next experiment and simultaneously has to be simulated numerically.

\section{Acknowledgment:}

The research is supported by JST/JICA SATREPS program on disaster prevention/mitigation measures against floods and storm surges in Bangladesh (PI: Dr. Hajime Nakagawa). The first author is pleased to acknowledge a Monbukagakusho (Ministry of Education,
Culture, Sports, Science and Technology, Japan) scholarship for graduate students.

\section{References}

1. Ullah W. M. and Rahman R. (2002). Tidal River Management: A sustainable solution to drainage congestion in the coastal region in Bangladesh Bangladesh Environment, 2, pp 1022-1032

2. Banglapedia (2012). The National Encyclopedia of Bangladesh revised Second Edition

3. Islam Md. S. et al (2013). Methodology of crest level design of coastal polders in Bangladesh $4^{\text {th }}$ International Conference on Water \& Flood Management

4. (BWDB) Bangladesh Water Development Board (2003). Khulna-Jessore Drainage Rehabilitation Project Final Report Part A: Monitoring and Integration

5. Leender de Die (2013). Tidal River Management: Temporary depoldering to mitigate drainage congestion in the southwest delta of Bangladesh MSc Thesis on Wageningen University, the Netherlands

6. Kibria Z. and Hirsch D. (2011). Tidal River Management: Climate Change Adaptation and Community based River Basin Management in Southwest Coastal Region of Bangladesh. Published by Uttaran.

7. Banglapedia (2004). National Encylopedia of Bangladesh, Asian Society of Bangladesh, $\mathbf{1}^{\text {st }}$ edition, Dhaka, Bangladesh

8. Hossain M. A. R. et al (2009). The Chalan beel in Bangladesh: Habitat and biodiversity degradation, and implications for future management Lakes \& Reservoirs: Research and Management, 14, 3-19

9. Tutu A. A. (2005). River Management in Bangladesh: A People's Initiative to Solve Water Logging, Civil Society and Poverty Reduction, International Institute for Environment and Development (IIED), No. 52, pp 117-123

10. EGIS (1998). Environmental and Social Impact Assessment of Khulna Jessore Drainage Rehabilitation Project, Dhaka.

11. IWM (2007), Monitoring the Effects of Beel Khuksia TRM Basin and Dredging of Hari River for Drainage Improvement of Bhabodaoh Area, Institute of Water Modelling (IWM), Dhaka, Bangladesh

12. Talchabhadel R., Nakagawa H. and Kawaike K. (2016). Experimental Study on Suspended Sediment Transport to represent Tidal Basin Management Journal of Japan Society of Civil Engineers, Ser. B1 (Hydraulic Engineering) Vol 72, No. 4, I_847-I_852

13. OpenCFD Ltd. OpenFOAM, The Open Source CFD Toolbox, User Guide, 2009.

14. OpenCFD Ltd. OpenFOAM, The Open Source CFD Toolbox, Programmer's Guide, 2009

15. Ota K., Sato T., and Nakagawa H. 3D numerical model of sediment transport considering transition from bed-load motion to suspension: application to 
local scours upstream of cross-river structures, JSCE, Vol.59, I_883- I_888, 2015. (in Japanese)

16. Khadim F. K. et al (2013). Integrated Water Resources Management (IWRM) Impacts in South West Coastal Zone of Bangladesh and Fact-Finding on Tidal River Management (TRM) Journal of Water Resource and Protection, 5, 953-961

17. (IWM) Institute for Water Modelling (2010). Feasibility Study and Detailed Engineering Design for Long Term Solution of Drainage Problems in the Bhabodah Area. 